\title{
Membrane module autopsy used in the reverse osmosis process
}

\section{Autopsia de un módulo de membranas utilizado en el proceso de ósmosis inversa}

ÁlVAREZ-SÁNCHEZ, Jesús †**, SANTACRUZ-MUNGARRO, Alma Delia, DÉVORA-ISIORDIA, Germán Eduardo and MARTÍNEZ-MACIAS, Maria del Rosario

Instituto Tecnológico de Sonora, Educational Program of Chemical Engineering, Department of Water and Environmental Sciences, February 5818 Sur Centro Cd. Obregón, Sonora 85000 Mexico.

ID $1^{\text {st }}$ Author: Jesús, Álvarez-Sánchez / ORC ID: 0000-0002-3773-6420, CVU CONACYT ID: 161848, SNI CONACYT ID: 55398

ID $1^{\text {st }}$ Coauthor: Alma Delia, Santacruz-Mungarro / ORC ID: 0000-0002-5343-5927, CVU CONACYT ID: 999174

ID $2^{\text {nd }}$ Coauthor: Germán Eduardo, Dévora-Isiordia / ORC ID: 0000-0002-0190-0794, CVU CONACYT ID: 163183, SNI CONACYT ID: 69496

ID $3^{\text {rd }}$ Coauthor: Maria del Rosario, Martínez-Macias / ORC ID: 0000-0002-3776-1327, CVU CONACYT ID: 248826, SNI CONACYT ID: 65338

DOI: $10.35429 / J E S N .2020 .18 .6 .9 .19$

Received July 15, 2020; Accepted December 30, 2020

\section{Abstract}

This research was done to get acquainted with the characteristic of the membrane module in spiral, used in the osmosis reverse process. The goal to know its measure, components, hydrophilic, topography, materials and performance. The membranes of the module were characterized by the next techniques: atomic force microscopy (AFM), infrared spectroscopy by ATR (Attenuated Total Reflectance), contact angle and crossflow equipment. Agree with the autopsy, the infrared spectrums indicate that the membrane is constituted by support of polyester paper, a polysulfone layer, a cellulose acetate layer and polyamide layer. The feed spacer is polypropylene and the permeate spacer is polyethylene terephthalate. All the measures did the membrane module were the same as the technical sheet from the manufacturer. The contact angle was $22.4 \pm 3.55^{\circ}$ and roughness of $182.43 \pm 42 \mathrm{~nm}$. The performance of the membrane was $70 \%$ to reject salts of feed 1000 ppm $\mathrm{Na}_{2} \mathrm{SO}_{4}$.

Membrane module, Membrane autopsy, Reverse osmosis

\section{Resumen}

Este trabajo de investigación se realizó para familiarizarse con las características de un módulo de membranas enrrolladas en espiral usado en el proceso de ósmosis inversa, con el objetivo de conocer sus medidas, componentes, hidrofilicidad, topografía, materiales y desempeño. Las membranas en el módulo fueron caracterizadas por las siguientes técnicas: microscopia de fuerza atómica (AFM), espectroscopía de infrarojo con ATR (reflectancia total atenuada), ángulo de contacto y equipo de flujo cruzado. De acuerdo a la autopsia, los espectros de infrarrojo de las membranas están constituida por un soporte de papel poliester, una capa de polisulfona, y una capa de acetato de celulosa y poliamida. La malla de alimentación es de polipropileno y la malla de permeado es polietileno tereftalato. Todas las medidas hechas al módulo fueron iguales a la hoja técnica del fabricante del módulo de membranas. El ángulo de contacto fue $22.4 \pm 3.55^{\circ}$ y una rugosidad de $182.43 \pm 42 \mathrm{~nm}$. El desempeño de la membrana en cuanto a rechazo de sales fue de $70 \%$ con una solución de alimentación de 1000 ppm de $\mathrm{Na}_{2} \mathrm{SO}_{4}$.

Módulo de membranas, Autopsia de membranas, Ósmosis inversa

Citation: ÁlVAREZ-SÁNCHEZ, Jesús, SANTACRUZ-MUNGARRO, Alma Delia, DÉVORA-ISIORDIA, Germán Eduardo and MARTÍNEZ-MACIAS, Maria del Rosario. Membrane module autopsy used in the reverse osmosis process. Journal of Environmental Sciences and Natural Resources. 2020. 6-18:9-19.

\footnotetext{
* Correspondence to Author (Email: jesus.alvarez@itson.edu.mx)

$\dagger$ Researcher contributing first author.
} 


\section{Introduction}

Today there is a great demand for fresh water and of course drinking water due to population growth, industrialization and technological development, etc.

Due to contamination and deterioration of rivers and underground aquifers, in many cases their use without prior treatment is unacceptable, even for industrial processes (Morote Seguido et al., 2017).

The parameters that intervene in any treatment for the purification of brackish or nonpotable water are energy, the nearby availability of water, the quality of the water, the final type of the process, etc. (Robles et al., 2019).

The applications of membrane processes are very extensive. Reverse osmosis (RO), ultrafiltration (UF), microfiltration (MF) and nanofiltration (NF), are techniques that have pressure as a driving force, they are widely used to produce drinking water, to convert saline water into drinking water, to treat waste water, in the food industry, to recover salts dissolved in water in industrial processes, to concentrate a polluting agent and up to a certain economic point.

RO treatments can improve water quality and is the most widely used treatment both industrially and for the production of drinking water in countries with insufficient water. It is a very easy process to carry out, although specialized labor is required for its proper operation, this allows the amortization of the initial investments in a feasible way (Payeras, 2015), the specialized labor guarantees us the proper management of the RO equipment, the proper functioning of the process, the care of the membranes, as well as the life time of the equipment, as well as that of the membranes used in the RO process will be the corresponding one. The reverse osmosis process occurs when two solutions with different concentrations are brought into contact through a semi-permeable membrane and a pressure greater than the osmotic pressure is applied to the concentrated solution in such a way that the water passes from the more concentrated solution to the most diluted.
The fundamental element in reverse osmosis are the membranes, which are arranged in modules inside pressure tubes. There are various configurations of modules, the most commonly used being the spiral wound type (Cifuentes, 2009).

The useful life of a membrane is related to the characteristics of the raw water, the hydraulic operating conditions, the chemical cleaning cycle and the fouling of the membrane. Membrane fouling refers to pore plugging and external pore blockage as a result of the deposition of particles and colloids on the membrane surface and the precipitation of smaller dissolved materials within the membrane pores. and on the surface of the membrane. A ratio of pore size to fouling size is important in determining the mechanisms involved in rejection and fouling. It is necessary to minimize membrane fouling because the decrease in permeate flux has enormous consequences on the economy and efficiency of the operation (Pontie et al., 2005; Chon \& Cho, 2016).

Analytical tools for membrane autopsies when fed with seawater are: zeta potential, atomic force microscopy (AFM), infrared spectroscopy with ATR (ATR-FTIR), hydraulic permeability, gravimetry, contact angle, salt rejection, Scanning electron microscopy (SEM), $\mathrm{X}$-ray diffractometry (XRD), X-ray fluorescence (XRF), sediment density index or fouling index (SDI), modified fouling index (MFI), nuclear magnetic resonance (NMR) (Pontie et al., 2005).

In Mexico, reverse osmosis desalination plants are being installed, which in part of the process are made up of membrane modules, in the cities of Nuevo León with a capacity of $29,184 \mathrm{~m}^{3} / \mathrm{d}$, Tampico 13,824 $\mathrm{m}^{3} / \mathrm{d}$, Los Cabos San Lucas $1892 \mathrm{~m}^{3} / \mathrm{d}$, Nava $1008 \mathrm{~m}^{3} / \mathrm{d}$, in Mexico City with a capacity of $273 \mathrm{~m}^{3} / \mathrm{d}$ and recently in Cochorit beaches, Empalme (Sonora) (Arreguín, 2015).

That is why laboratories seek to know and characterize the membranes used in the reverse osmosis process, to develop better membranes, and innovate in the regeneration of membranes. This would be very important since Mexico does not have laboratories of this type. 
Therefore, the objective of this is to know the characteristics of a spiral wound membrane module, used in the reverse osmosis process, identifying its physical and chemical characteristics such as measurements, components, hydrophilicity, topography, materials and performance. The membranes in the module were characterized by AFM, infrared spectroscopy with ATR (attenuated total reflectance), contact angle and crossflow equipment.

\section{Methodology}

\section{Material}

Membrane module model TW30-4040, tape, scissors, rulers, gloves, vernier, tape measure, tweezers, handsaw, pocketknife and hacksaw.

\section{Equipment}

Calibrator, Mitutoyo Model 7300S Micrometer, Stopwatch, YSI Model 30 Conductivity Meter, Explorer OHAUS Model E12140 Digital Analytical Balance, Dataphysics Contact Angle Equipment Model OCA 15EC, Infrared Equipment by ATR Thermo Scientific Model Nicolet iS5, Sterlitech Corporation Cross Flow Equipment Model CF042 and atomic force microscope equipment AFM Workshop model TT-AFM.

\section{Methodologies for the autopsy of a module used in the reverse osmosis process}

The membrane module was identified, and they were extracted by opening the module removing the side covers, the protective tape of the membrane module was removed to identify the conformation of the membrane module inside (Figure 1).

Cleaning corresponding to the module was carried out and the number of layers of the membrane module was counted.

These layers were measured in length and width of the module, as well as the diameters of the feeding and rejection tubes. These same measurements were carried out on the mesh and the waterproof separator.
A membrane was then cut into a $7 \mathrm{~cm}$ by $5 \mathrm{~cm}$ rectangle to be characterized by Dataphysics contact angle equipment, model OCA 15EC, infrared equipment by ATR Thermo Scientific, model Nicolet iS5, AFM atomic force microscope equipment Workshop, model TTAFM and finally the Sterlitech Corporation cross flow equipment, model CF042. Figure 1 shows a block diagram with the methodology used for the autopsy of a spiral membrane module.

\section{Membrane characterization}

\section{Contact angle}

The contact angle analysis was performed on a Dataphysics equipment, model OCA 15EC, using the SCA20 software. The membranes were cut to a dimension of $3 \mathrm{~cm} \times 2 \mathrm{~cm}$ and then placed on the base of the equipment with tape. Distilled water was placed inside the syringe (previously filtered with a $0.2 \mu \mathrm{m}$ filter). Subsequently, the measurements were made by applying five drops of water on the membrane, placing each drop at different points on the surface in a rectangular arrangement, leaving an approximate distance of half a centimeter between each measurement.

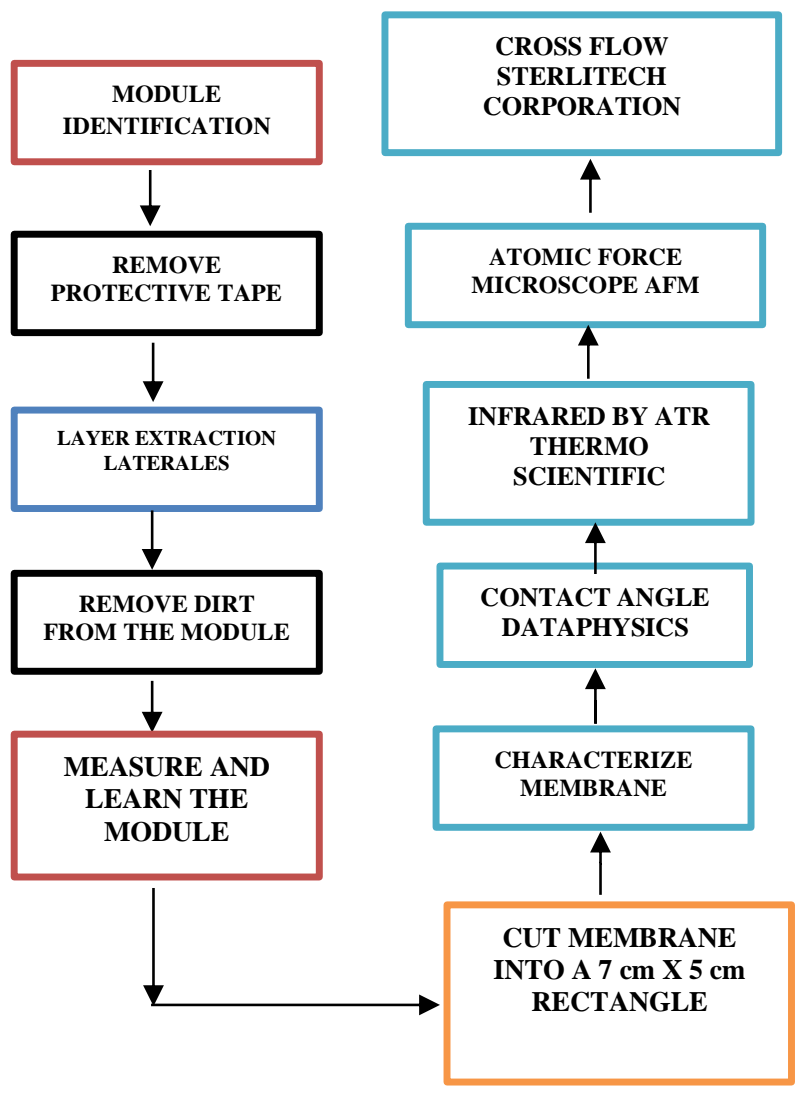

Figure 1 Diagram of methodologies for the autopsy of a module used in the reverse osmosis process Source: Self made 


\section{Infrared ATR Spectrophotometer}

The identification of functional groups of the composite membranes was carried out with the infrared equipment by ATR Thermo Scientific, model Nicolet iS5. Membranes were cut for testing to a dimension of $1 \mathrm{~cm} \times 1 \mathrm{~cm}$. Subsequently, the sample was taken with tweezers, holding it by the edge, avoiding contact with the face of the polymer, and it was placed on the analysis base with the face down. The screw of the base was adjusted in order to have a better image of the sample (which is interpreted by the OMNIC software), and the analysis was started. The same procedure was repeated for each of the samples analyzed.

\section{Atomic force microscope}

The leveling of the AFM Workshop atomic force microscope, model TT-AFM, was verified. Each membrane to be analyzed was cut to a dimension of $0.5 \mathrm{~cm} \times 0.5 \mathrm{~cm}$, and they were glued to the base of the equipment. Once the sample was placed, the AFM $50 \mu \mathrm{m}$ software was started, then the camera was focused and a small tip called a cantiliver was brought close to the sample, which is in charge of scanning the sample. A measurement was made for the membrane sample, using scan area of $10 \mu \mathrm{m} \times 10$ $\mu \mathrm{m}$.

\section{Cross flow}

The cross-flow equipment (Figure 2) works by passing a saline solution found in the tank (1) through a cell (3) that contains inside one of the membranes tested in this investigation, contains a pump (2) that raises the pressure of the fluid to levels greater than the osmotic pressure, so that the fluid can pass through the membrane. The cell contains two fluid outlets, the first is for the permeate fluid (E, product), which contains a smaller quantity of salts after passing it through the membrane and the second, has the name of rejection (C) which it returns to the tank (1), the stream where the greatest amount of salts is concentrated, that is, it contains the salts from the feed plus the salts that did not pass through the membrane.
With this equipment, the performance of the membrane was analyzed in terms of salt rejection (ppm), pressure (8, in $\mathrm{MPa}$ ) and permeate flow (in $\mathrm{ml} / \mathrm{min}$ ). In Figure 2, the main components of the crossflow equipment are shown. The equipment has 2 valves (4 and 7) to regulate the flows. A balance to weigh the permeate (6) and a tank to receive it (5).

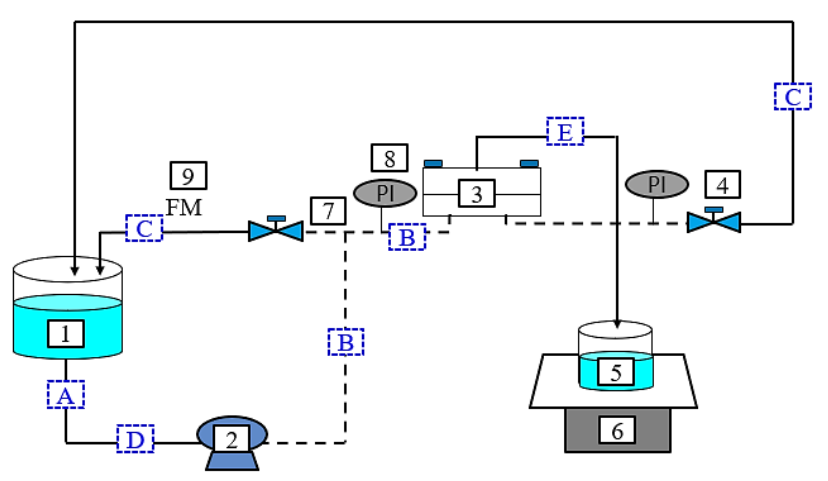

Figure 2 Cross-flow equipment (1. Feed tank (19 L), 2. Pump (1.5 hp), 3. Permeate cell, 4. Needle valve to control pressure, 5. Tank (250 mL), 6. Balance, 7. Dump valve, 8 . Pressure gauge and 9 . Flow meter $\mathrm{A}=$ rigid stainless steel tube, $\mathrm{D}=\mathrm{PVC}$ tube, $\mathrm{E}=$ Nylon hose, $\mathrm{B}$ and $\mathrm{C}=$ hose with 1,000 psia resistance.).

Source: Self made

Once the membrane module was dismantled, a $11.5 \mathrm{~cm} \times 6 \mathrm{~cm}$ piece was cut out to be placed inside the cell of the crossflow equipment. Prior to trimming, a saline solution was prepared at $1,000 \mathrm{ppm}$ of $\mathrm{Na}_{2} \mathrm{SO}_{4}$ in a volume of $10 \mathrm{~L}$, it was emptied into the feeding container of the system. The reject flow outlet valve was fully opened to let any air that may be inside the system escape and gradually close it, until reaching the desired pressure of $4.14 \mathrm{MPa}$, once the high-pressure pump was turned on. Once the system is stable, the flow or permeate product is collected in a container to later measure the salt concentration in ppm with the conductivity meter, and while the desired permeate volume is obtained, the time is measured. Obtained both concentrations $\mathrm{C}_{1}$ and $\mathrm{C}_{2}$ (concentration of the feed and concentration of the permeate respectively), equation 1 is applied to determine the percentage of rejection of salts $(\% \mathrm{R})$ and equation 3 for the flow rate or permeate flow.

$\% R=\frac{C_{1}-C_{2}}{C_{1}} * 100 \%$ 
The following Figure 3 shows the flows or flows that were generated during the process, from which we can distinguish: Feed flow or flow, which is the one to be desalinated and is applied to one side of the membrane, Fa; permeate flow or flow (product), which corresponds to the water from which the salts have been eliminated or reduced, Fp; flow or flow of the concentrate (rejection), which drags the salts that have been separated by the membrane and that will be deposited on it, Fr.

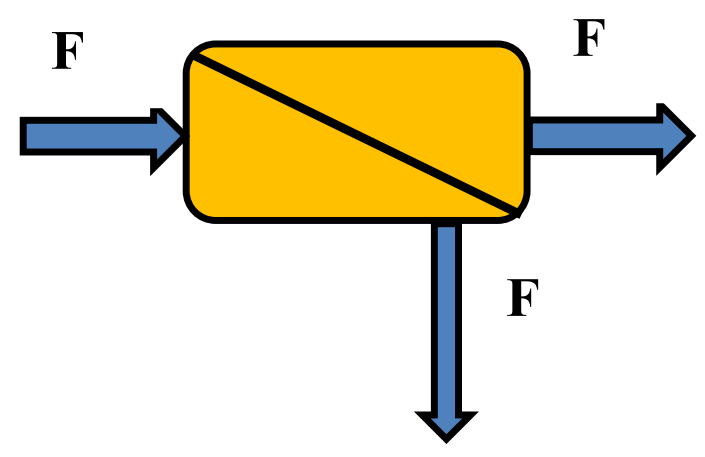

Figure 3 Flows in the reverse osmosis process. Source: Self made

The equation to calculate the above magnitudes are:

$\mathrm{F}_{\mathrm{a}}=\mathrm{F}_{\mathrm{p}}+\mathrm{F}_{\mathrm{r}}$

Also

$\mathrm{F}_{\mathrm{p}}=\frac{V}{\Delta t}$

Where:

$$
\begin{aligned}
& \mathrm{V}=\text { Volume } \\
& \Delta \mathrm{t}=\text { Time differential }
\end{aligned}
$$

\section{Results}

\section{Membrane module characterization}

The results obtained were as follows: it is a spiral-type membrane module formed by 26 rectangular layers wound (Figure 4) around a cylindrical axis with perforations (Figure 5).
The module is made up of 6 membranes, 6 meshes and 6 waterproof spacers that are rolled and glued by epoxy resin (Figure 6), the length module measures $97.79 \mathrm{~cm}$ (Figure 7), the external diameter of the permeate tube measures $2.6 \mathrm{~cm}$ (Figure 8), the diameter of the feed flow is $9.9 \mathrm{~cm}$, the mesh, membrane and waterproof separator measures $80.01 \mathrm{~cm}$ wide and $92.71 \mathrm{~cm}$ long (Figure 9). When the module was opened, it gave off dirt (Figure 10).

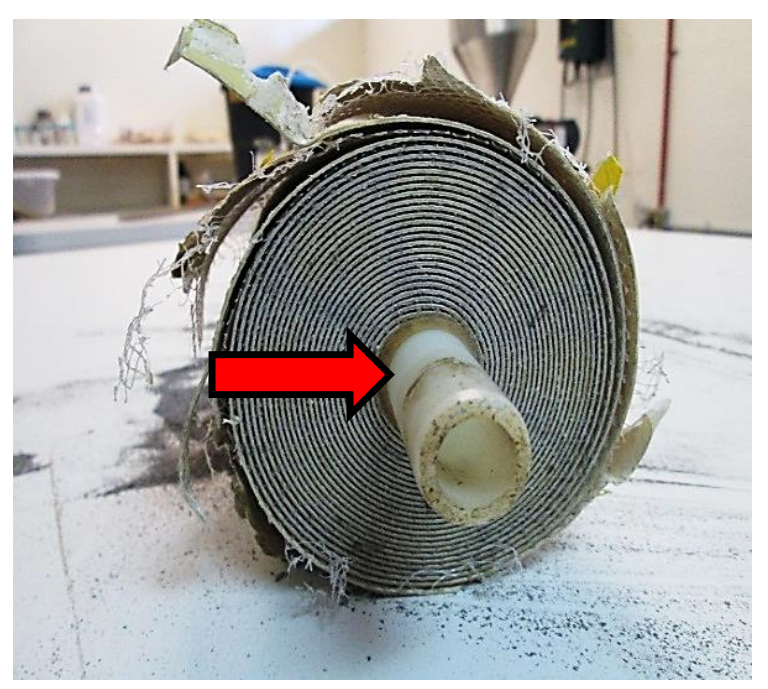

Figure 4 Layers of membranes Source: Self made

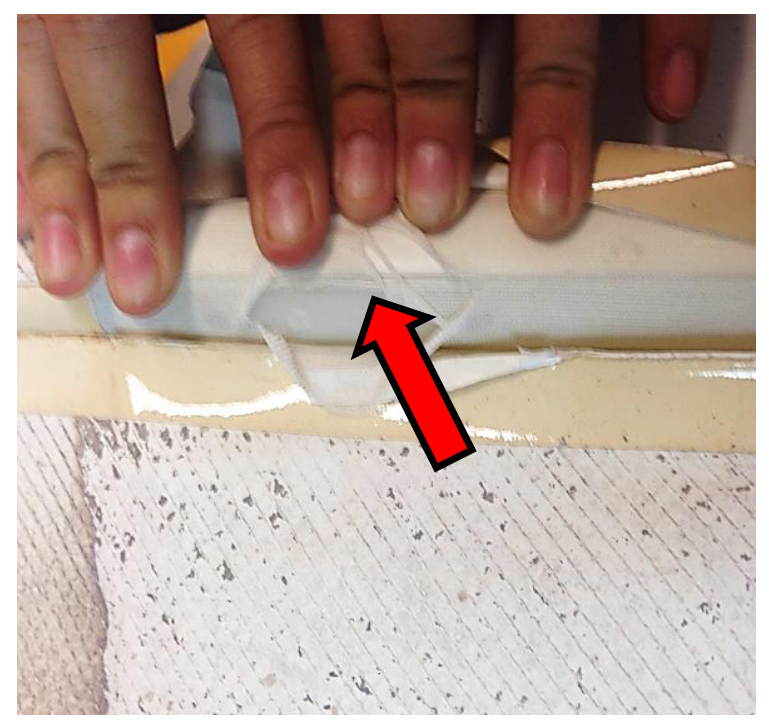

Figure 5 Tube with perforations Source: Self made 


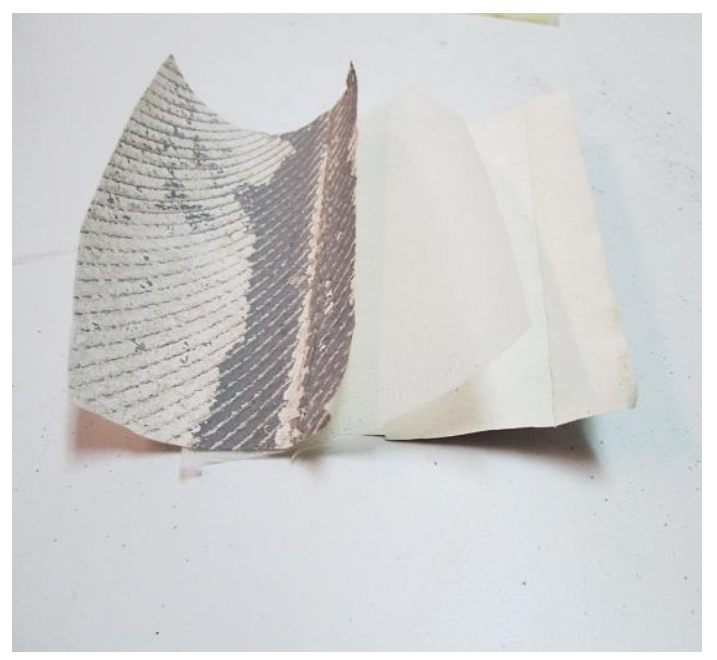

Figure 6 Membranes, meshes and waterproof separator Source: Self made

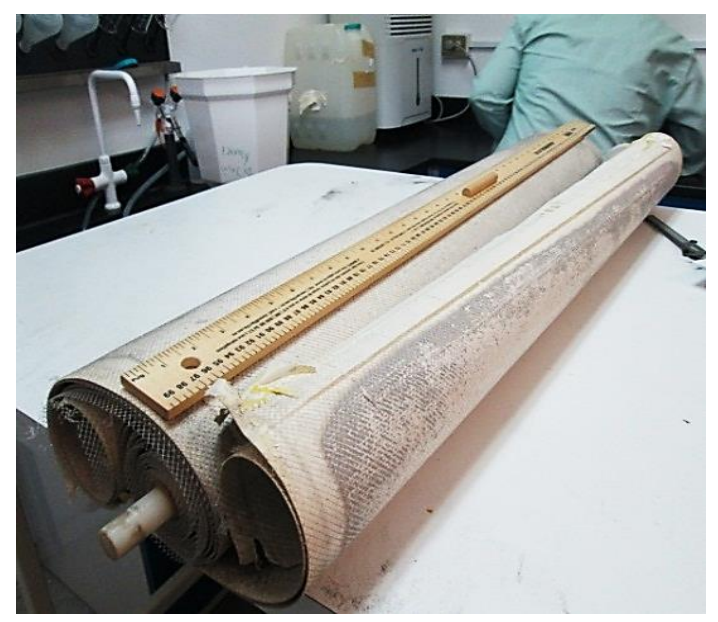

Figure 7 Modulus measurement Source: Self made

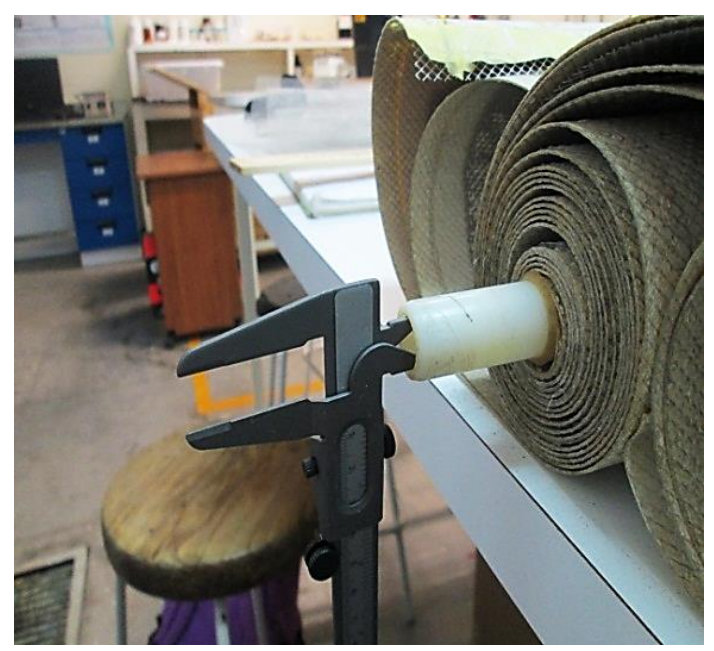

Figure 8 Measure diameter Source: Self made

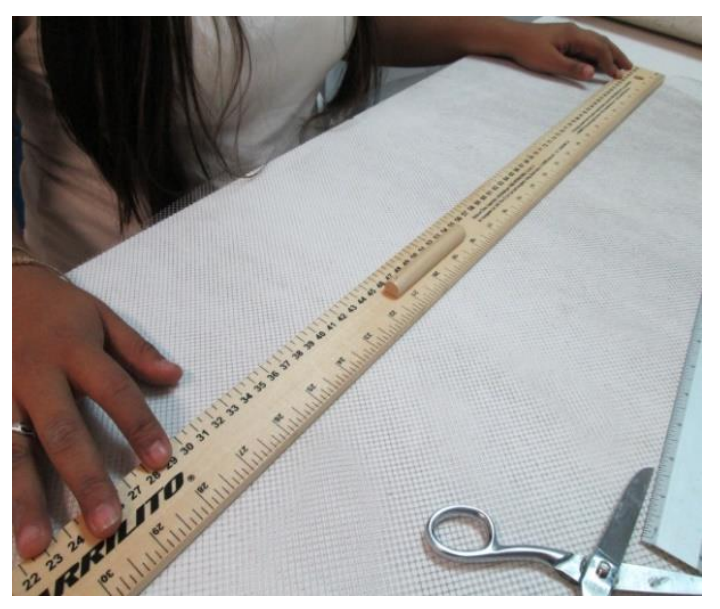

Figure 9 Membrane measurement Source: Self made

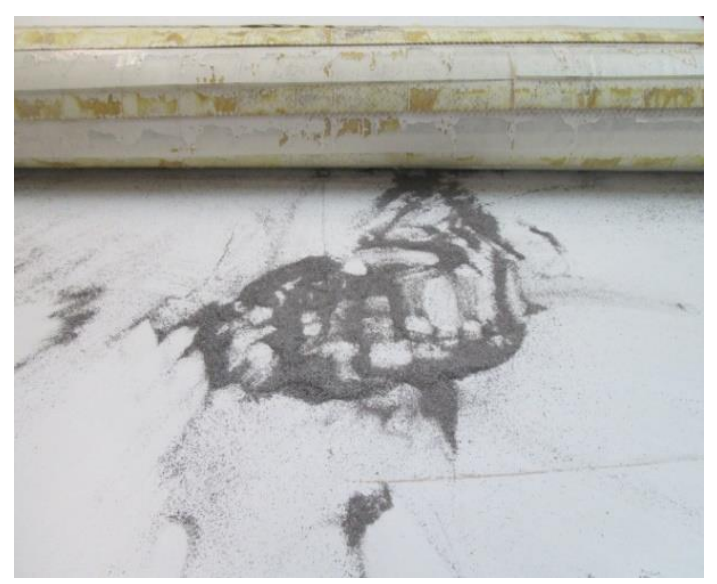

Figure 10 Dirt of the membrane module Source: Self made

The results were corroborated on the page (Figure 11 and table 1) of the company that manufactures the characterized membrane, the model is TW30-4040 obtaining identical results.

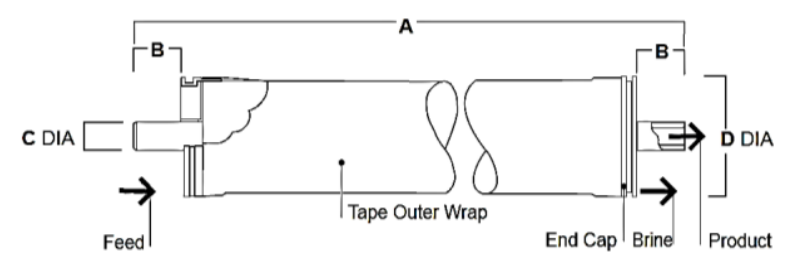

Figure 11 Characteristics of the membrane module model TW3O-4040

Source: DOW FILMTEC тм, 2020

\begin{tabular}{|l|r|r|}
\hline Measurements & \multicolumn{1}{c}{$\begin{array}{c}\text { Module } \\
\text { analyzed }\end{array}$} & \multicolumn{1}{c|}{$\begin{array}{c}\text { TW30-4040 } \\
\text { Vendor Module }\end{array}$} \\
\hline Measure A & $100.39 \mathrm{~cm}$ & $40 \mathrm{in} / 101.16 \mathrm{~cm}$ \\
\hline Measure B & $2.6 \mathrm{~cm}$ & $1.05 \mathrm{in} / 2.67 \mathrm{~cm}$ \\
\hline Measure C & $1.90 \mathrm{~cm}$ & $0.75 \mathrm{in} / 1.9 \mathrm{~cm}$ \\
\hline Measure D & $9.9 \mathrm{~cm}$ & $3.9 \mathrm{in} / 9.9 \mathrm{~cm}$ \\
\hline
\end{tabular}

Table 1 Comparisons of the measures of the analyzed module and those of the supplier Source: Self made

ÁLVAREZ-SÁNCHEZ, Jesús, SANTACRUZ-MUNGARRO, Alma Delia, DÉVORA-ISIORDIA, Germán Eduardo and MARTÍNEZ-MACIAS, Maria del Rosario. Membrane module autopsy used in the reverse osmosis process. Journal of Environmental Sciences and Natural Resources. 2020 


\section{Contact angle measurement}

The average contact angle of the membrane was $22.4 \pm 3.55^{\circ}$ (Table 2). The membrane presents at a low angle with respect to the criterion that the liquid moistens the solid (by convention $\Theta<90^{\circ}$ ) being an angle less than $90^{\circ}$ which implies that the membrane has an affinity for water. This is desirable in reverse osmosis because there is more permeate flow.

\begin{tabular}{|l|r|}
\hline $\begin{array}{c}\text { Measure } \\
\text { number }\end{array}$ & \multicolumn{1}{|}{$\left(^{\circ}\right)$} \\
\hline 1 & 20.3 \\
\hline 2 & 18.2 \\
\hline 3 & 22.3 \\
\hline 4 & 27.6 \\
\hline 5 & 23.5 \\
\hline Average & 22.4 \\
\hline $\begin{array}{l}\text { Standard } \\
\text { deviation }\end{array}$ & \pm 3.55 \\
\hline
\end{tabular}

Table 2 Diaphragm contact angle Source: Self made

\section{Infrared spectra of the parts that make up the membrane module}

\section{Reverse of the membrane}

Polysulfone is constituted in its monomeric unit (Figure 12) by 4 aromatic rings $\left(\mathrm{C}_{6} \mathrm{H}_{4}\right), 2$ methyls $\left(-\mathrm{CH}_{3}\right)$, the functional group ether (ar-O-ar), sulfone group $\left(\mathrm{SO}_{2}\right)$.

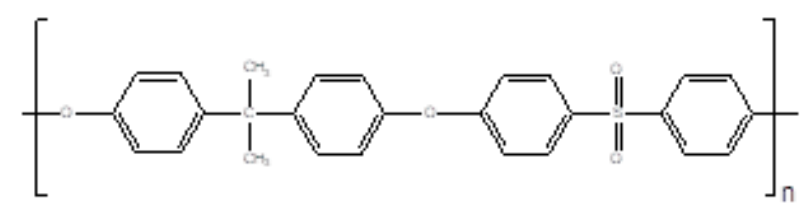

Figure 12 Chemical structure of polysulfone Source: Self made

The paper was separated from the membrane and the reverse of the membrane was analyzed obtaining its infrared spectrum (Figure 13). The main signals of the infrared spectrum were then analyzed.

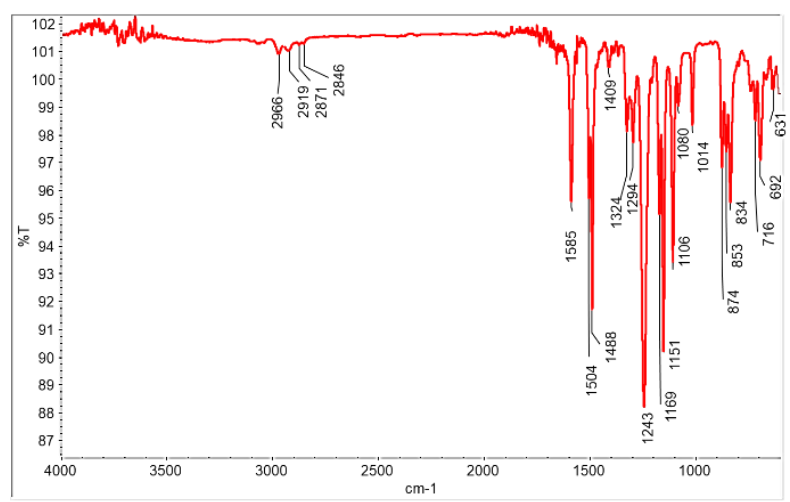

Figure 13 Infrared spectrum of the reverse side of the membrane

Source: Self made

$\mathrm{Csp}_{2}-\mathrm{H}$ stretching of aromatic ring at $3,070 \mathrm{~cm}^{-1}$, asymmetric stretching of $\mathrm{CH}_{3}$ at $2,966 \mathrm{~cm}^{-1}$, symmetric stretching of $\mathrm{CH}_{3}$ at 2,873 $\mathrm{cm}^{-1}$, stretching of $\mathrm{CH}_{3}$ behaving as a $\mathrm{CH}_{2}$ at $2927 \mathrm{~cm}^{-1}$ and $\mathrm{CH}_{2}$ at $2845 \mathrm{~cm}^{-1}$, but they are very weak signals due to the type of analysis technique and also due to the intensity of the $\mathrm{CO}$ signal.

Stretch $\mathrm{C}=\mathrm{C}$ of aromatic at $1.585 \mathrm{~cm}^{-1}$, the signals $1.504 \mathrm{~cm}^{-1}$ and $1.48 \mathrm{~cm}-1$ are also due to the $\mathrm{C}=\mathrm{C}$ of aromatic (Pavia et al., 2009).

Asymmetric stretching of the $\mathrm{O}=\mathrm{S}=\mathrm{O}$ at $1,324 \mathrm{~cm}^{-1}$ the signal is weak and symmetric stretching of the sulfone functional group at $1,151 \mathrm{~cm}^{-1}$ which is strong (Pavia et al., 2009). C$\mathrm{O}$ stretching of an aromatic-linked ether shows the signal at $1.243 \mathrm{~cm}^{-1}$ and $1.080 \mathrm{~cm}^{-1}$.

The $834 \mathrm{~cm}^{-1}$ signal indicates that they are aromatic rings disubstituted in position for this according to the chemical structure (Figure 12) and Pavia et al. (2009). Therefore, it is corroborated that the reverse of the analyzed membrane is prepared with polysulfone.

\section{Thin layer of aromatic polyamide}

The surface of the membrane was analyzed, which the manufacturer indicates that it is aromatic polyamide (Figure 14, FILMTECTM, 2020). The spectrum of aromatic polyamide and polysulfone was clouded by a very intense signal (Figure 15, $1044.01 \mathrm{~cm}^{-1}$ ), which could be the CO signal of cellulose acetate (Figure 15). 


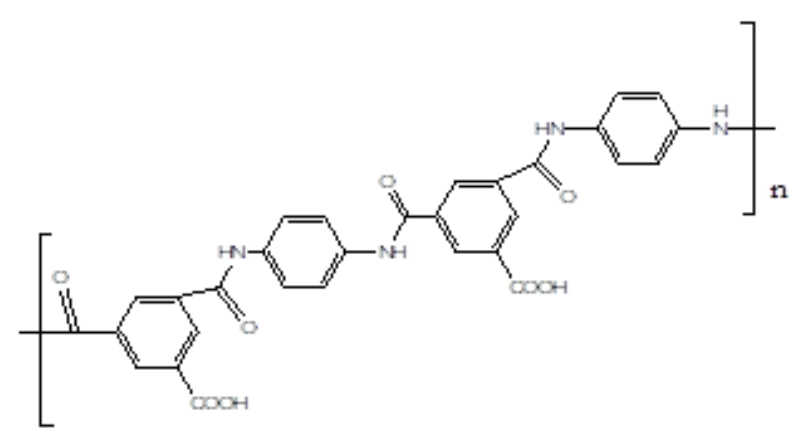

Figure 14 Chemical structure of aromatic polyamide Source: Self made

In Figure 15 you can see the signal at $1654 \mathrm{~cm}^{-1}$ corresponds to the carbonyl group of the amide functional group (R-CO-NH-R) and the signal 1735 corresponds to the carbonyl group of a carboxylic acid, this functional group is added to increase the hydrophilicity of the membranes.

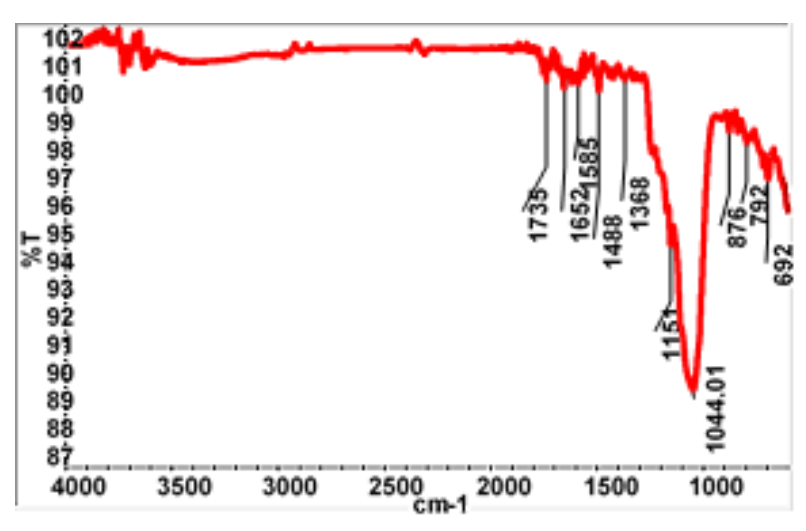

Figure 15 Spectrum of the membrane used in the reverse osmosis process

Source: Self made

According to the autopsy, the infrared spectra and the contact angle, the membrane is made up of a polyester paper support, a polysulfone layer, and a cellulose acetate and polyamide layer. Apparently, the thin layer is polyamide, it is a combination of aromatic polyamide and cellulose.

\section{Permeate mesh}

The permeate mesh was analyzed by infrared spectroscopy, which showed a spectrum (Figure 16), which resulted in the mesh material being polyethylene terephthalate when comparing the infrared spectrum of the permeate mesh against the OMNIC software library with a coincidence in signals of 64\% (Figure 17), in Table 3 we can see the comparisons of the signals of the spectra of polyethylene terephthalate (San Andres et al., 2010) and of the permeate mesh, the signals are very similar.
Polyethylene terephthalate is constituted in its monomeric unit of $-\mathrm{CH}_{2-}$, ester functional group $\mathrm{R}-\mathrm{COO}-\mathrm{R}$, the $\mathrm{C}-\mathrm{O}$ bond, $\mathrm{C}=\mathrm{O}$ carbonyl group and benzene ring (Figure 16).

\begin{tabular}{|c|c|c|}
\hline Signal & $\begin{array}{l}\text { Wave number } \\
\quad\left(\mathrm{cm}^{1}\right) \\
\text { Polyethylene } \\
\text { terephthalate }\end{array}$ & $\begin{array}{l}\text { Wave number } \\
\left(\mathrm{cm}^{-1}\right) \\
\text { (permeate } \\
\text { mesh) }\end{array}$ \\
\hline$-\mathrm{CH}_{2-}$ & 2965 y 2913 & 2963 \\
\hline $\mathrm{C}=\mathrm{O}$ & 1713 & 1715 \\
\hline $\mathrm{C}=\mathrm{C}$ & $1615,1580,1505$ & $\begin{array}{r}1603,1587 \text { and } \\
1508 \\
\end{array}$ \\
\hline $\mathrm{C}-\mathrm{H}$ & $\begin{array}{r}1470,1410,1372 \\
\text { and } 1340 \\
\end{array}$ & $\begin{array}{r}1476,1409 \\
1340 \\
\end{array}$ \\
\hline$[\mathrm{C}-\mathrm{C}(\mathrm{O})-\mathrm{O}]$ & 1240 & 1251 \\
\hline [-O-C- $]$ & 1120 and 1098 & 1126 \\
\hline $\begin{array}{l}\text { In the } \mathrm{C}-\mathrm{H} \\
\text { plane }\end{array}$ & 1016 and 970 & 1020 and 970 \\
\hline $\begin{array}{l}\text { Outside the } \\
\text { C-H plane }\end{array}$ & 870 & 872 \\
\hline Heading C-H & 720 & 724 \\
\hline
\end{tabular}

Table 3 Infrared spectrum signals from polyethylene terephthalate and permeate mesh

Source: Self made

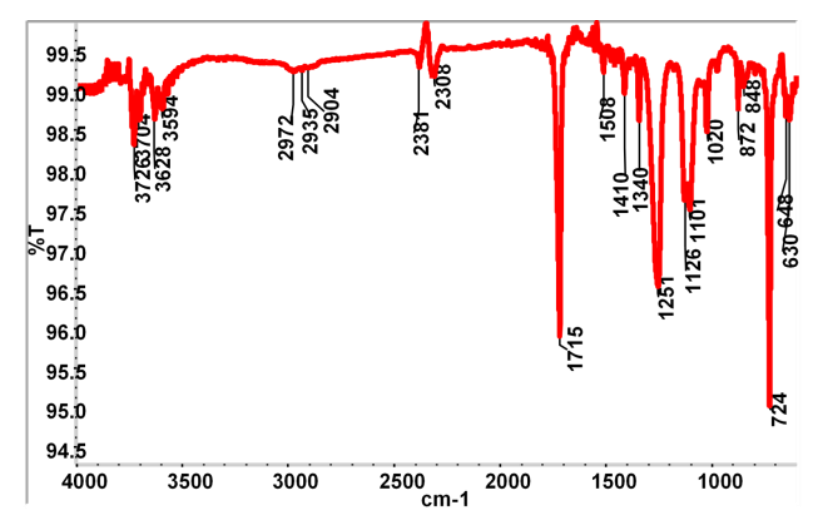

Figure 16 Infrared spectrum of the permeate mesh Source: Self made

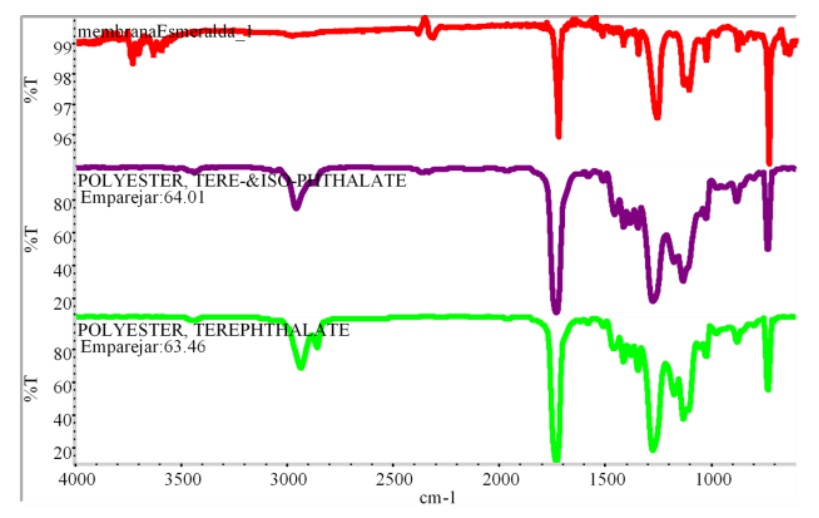

Figure 17 Infrared spectrum comparison of the permeate mesh against the OMNIC library Source: Self made

ÁLVAREZ-SÁNCHEZ, Jesús, SANTACRUZ-MUNGARRO, Alma Delia, DÉVORA-ISIORDIA, Germán Eduardo and MARTÍNEZ-MACIAS, Maria del Rosario. Membrane module autopsy used in the reverse osmosis process. Journal of Environmental Sciences and Natural Resources. 2020 


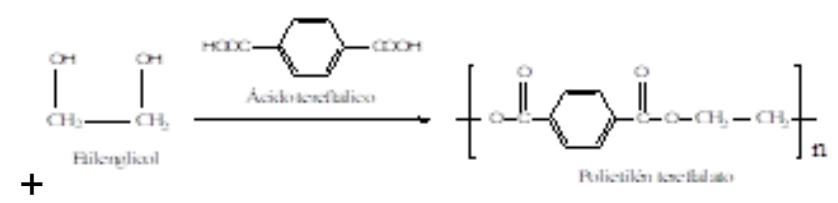

Figure 18 Chemical structure of polyester terephthalate and its monomers

Source: (Tiravanti, 2011)

\section{Feeding mesh}

Infrared spectroscopy analysis was performed for the feeding mesh, according to the infrared spectra library of the OMNIC software, the polymer was polypropylene because it has a $79 \%$ coincidence (Figure 19). The chemical structure of the monomeric unit of the polymer is $-\mathrm{CH}_{2}-$, $\mathrm{CH}, \mathrm{CH}_{3}$ (Figure 20) Table 4 shows the infrared spectrum signals for polypropylene.

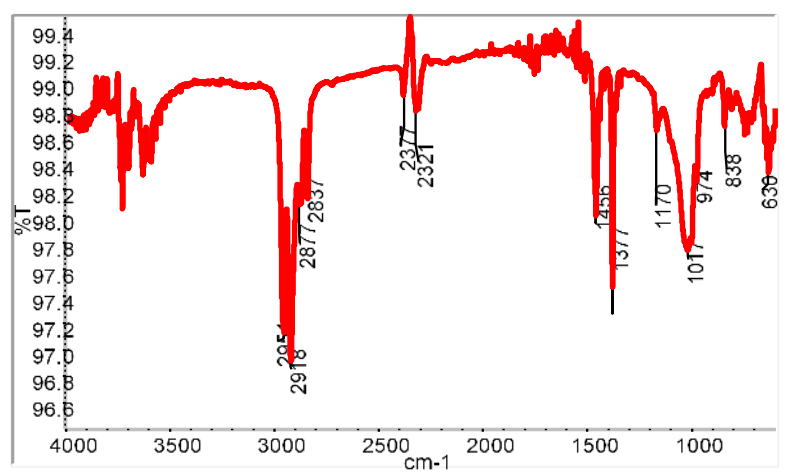

Figure 19 Infrared spectrum of the feed mesh. Source: Self made

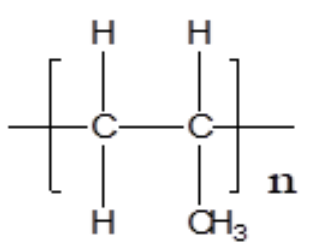

Polypropylene

Figure 20 Chemical structure of polypropylene Source: Self made

\begin{tabular}{|l|r|}
\hline \multicolumn{1}{|c|}{ Signal } & Wave number $\left.\mathbf{( c m}^{-1}\right)$ \\
\hline $\mathrm{CH}_{3}$ Asymmetric stretch & 2951 \\
\hline $\mathrm{CH}_{2}$ Asymmetric stretch & 2918 \\
\hline $\mathrm{CH}_{3}$ Symmetrical stretch & 2877 \\
\hline $\mathrm{CH}_{2}$ Symmetrical stretch & 2837 \\
\hline $\mathrm{CH}_{3}$ Asymmetric deformation & 1456 \\
\hline $\mathrm{CH}_{3}$ Symmetric deformation & 1377 \\
\hline $\mathrm{CH}_{2}$ Symmetric deformation & 732 \\
\hline
\end{tabular}

Table 4 Infrared spectrum signals from the feed mesh Source: Self made

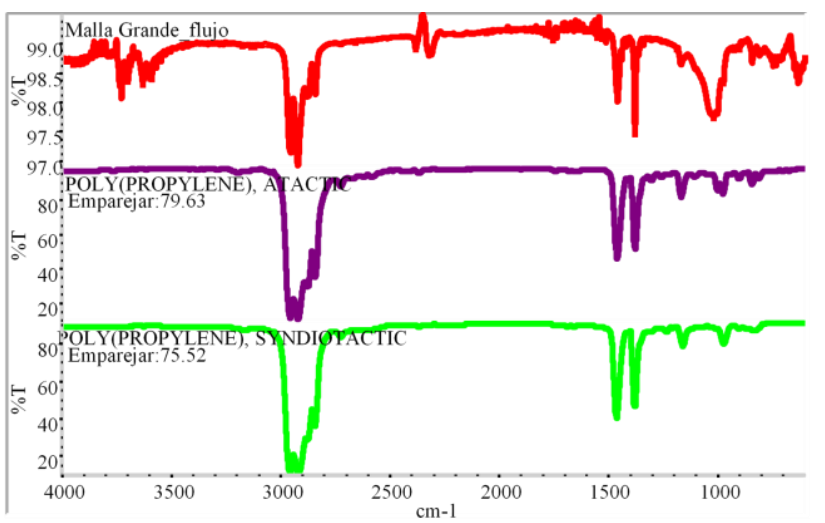

Figure 21 Infrared spectrum of feed mesh against OMNIC software library

Source: Self made

\section{Characterization by Atomic Force Microscopy}

The average roughness was $182.43 \mathrm{~nm}$ with a standard deviation of $\pm 42 \mathrm{~nm}$ (Table 5). The colors in the image are based on the color spectrum shown in Figure 22. The lilac color indicates that it is the highest height of the peak or in other words the highest roughness, followed by navy blue, then blue sky and so on until reaching the black color which is the lowest roughness or the lowest height. It can be seen that the green color predominates, which is located in the middle of the color spectrum. Returning to the value of the RMS indicates that the roughness in the membrane is not very high, which is good because in this way the biofouling and the probability of incrustations of organic and inorganic chemical compounds is reduced. Comparing the membranes of the module with the membranes prepared by Álvarez et al. (2014), the roughness is very similar. But if we compare them with the membranes of (Yu et al., 2009). These have $30 \mathrm{~nm}$ roughness (RMS) the characterized module membranes have 6.4 times greater roughness. It must be taken into account that the membrane module was in use for at least 2 years, exposed to high pressures, bio-fouling and chemical fouling.

\begin{tabular}{|l|r|}
\hline Measure number & $\begin{array}{c}\text { Roughness } \\
\text { RMS * } \\
\text { (nm) }\end{array}$ \\
\hline 1 & 224.8 \\
\hline 2 & 181.7 \\
\hline 3 & 140.8 \\
\hline Average & 182.43 \\
\hline $\begin{array}{l}\text { Standard } \\
\text { deviation }\end{array}$ \\
\hline \multicolumn{2}{|c|}{ *RMS: Mean square root } \\
\hline
\end{tabular}

Table 5 Membrane roughness

Source: Self made

ÁLVAREZ-SÁNCHEZ, Jesús, SANTACRUZ-MUNGARRO, Alma Delia, DÉVORA-ISIORDIA, Germán Eduardo and MARTÍNEZ-MACIAS, Maria del Rosario. Membrane module autopsy used in the reverse osmosis process. Journal of Environmental Sciences and Natural Resources. 2020 

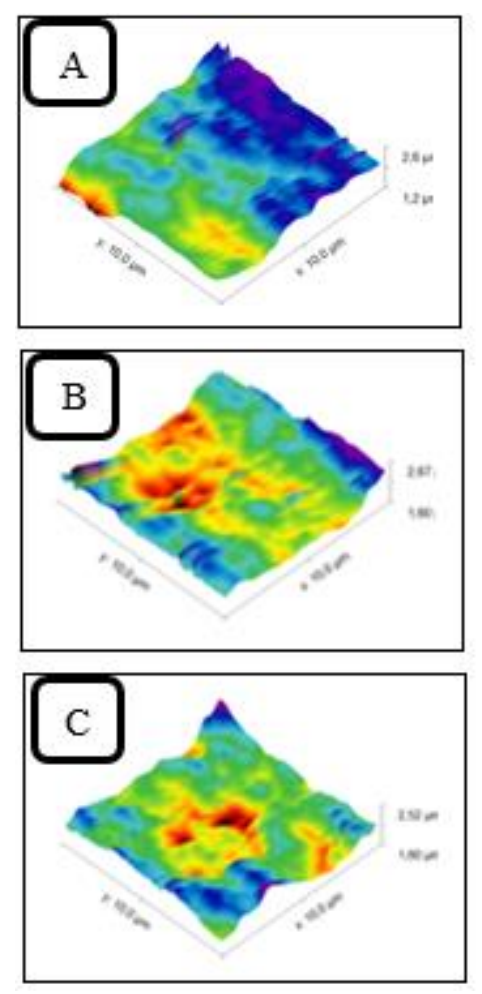

Figure 22 Membrane roughness by AFM Source: Self made

\section{Performance in the cross-flow team}

A saline solution of $1000 \mathrm{ppm}$ of sodium sulfate $\left(\mathrm{Na}_{2} \mathrm{SO}_{4}\right)$ was prepared to feed the equipment, the membrane already used in the reverse osmosis process was tested under appropriate conditions at a constant pressure of $4.14 \mathrm{MPa}$, the feed flow was maintained constant at $0.6 \mathrm{~L} / \mathrm{min}$, in a time of $40 \mathrm{~min}$ a permeate flow of $2.6 \mathrm{~mL} / \mathrm{min}$ was obtained. Using equation 1 , the percent removal of salts was obtained, which was a removal of $70 \%$. The result obtained is clear that the membrane is damaged because it removes $29 \%$ less salts. The operating pressure indicates that the membrane is fouled because the technical sheet reveals that a pressure of $1.55 \mathrm{MPa}$ can obtain a permeate flow of $3.6863 \mathrm{ml} / \mathrm{min}$ (DOW FILMTEC TM, 2020). 29.5\% less permeate flow was obtained.

\section{Conclusions}

During the autopsy of the module it was observed that it is a spiral arrangement. To investigate the cause of the damage found in the membrane, its surface characterization was carried out using the atomic force microscope, resulting in an average roughness of $182.43 \pm 42 \mathrm{~nm}$. The roughness in the membrane is not very high, which is favorable because it reduces bio-fouling and chemical encrustations.
When analyzing the membrane by the contact angle measuring equipment, a low angle of $22.4 \pm 3.55^{\circ}$ was obtained, an angle less than $90^{\circ}$, which indicates that the membrane has an affinity for water. This is favorable in reverse osmosis because there is more permeate flow.

The membrane was tested in the crossflow equipment removing $70 \%$ of salts $\left(\mathrm{Na}_{2} \mathrm{SO}_{4}\right)$, which indicates that the membrane is not working well, because the specifications in the technical sheet mention that it can remove salts up to $99 \%$, also the operating pressure was very high, which is an indication that the membrane has fouling. Through infrared spectrometry analysis, it was concluded that the membrane is composed of a layer of polysulfone, polyamide and cellulose acetate, the feeding mesh that is made of polypropylene polymer and the permeate mesh that It is made of polyester terephthalate polymer.

With the results obtained, the objective of the membrane module autopsy was met, which was to characterize and analyze the membrane by the different teams.

In Mexico there is still no special laboratory to perform membrane autopsy. However, ITSON has already started with this topic in the Research Laboratory in Chemical and Food Engineering (LIIQA) interior Polymers and Materials.

\section{Acknowledgments}

To the Technological Institute of Sonora for the infrastructure provided and for the financing provided through the Support and Promotion Program for Research Projects (PROFAPI). We are also grateful to the National Council of Science and Technology (CONACyT) for the financing for the acquisition of equipment and to the Program for Teacher Professional Development (PRODEP) for the financing granted.

\section{References}

Álvarez-Sánchez, J., Encinas-Meneses, E., Pérez-Sicairos, E., Ríos-Vazquez, N. J., DévoraIsiordia, G. E. \& González-Enríquez, R. (2014). Preparación y caracterización de membranas compuestas elaboradas a partir de 2,4,6 Trimetil m-Fenilendiamina y Cloruro de Trimesoílo. Revista Iberoamericana de Ciencias, 1:7, 123136.

ÁLVAREZ-SÁNCHEZ, Jesús, SANTACRUZ-MUNGARRO, Alma Delia, DÉVORA-ISIORDIA, Germán Eduardo and MARTÍNEZ-MACIAS, Maria del Rosario. Membrane module autopsy used in the reverse osmosis process. Journal of Environmental Sciences and Natural Resources. 2020 
Arreguín Cortés Felipe I. Director General de Instituto Mexicano de Tecnología del Agua (IMTA), Blog (2/11/2015). Recuperado el 12 de noviembre del 2020 de https://www.iagua.es/blogs/felipe-arreguin/bajacalifornia-y-quintana-roo-pioneros-desalacionmexico

Cifuentes, N. (2009). Tratamientos del Agua con Membranas. Tesis doctoral Barcelona, España.

Chon, K. \& Cho, J. (2016). Fouling behavior of dissolved organic matter innanofiltration membranes from a pilot-scaledrinking water treatment plant: An autopsy study. Chemical Engineering Journal, 295,268-277.

Cornell. (1995). Tratamiento de Agua por Osmosis Inversa. Argentina Recuperado el 22 de Marzo del 2017 de, http://www.prowaterargentina.com.ar/articulos/INF O_OSM_INV_06.pdf.

DOW FILMTECTM Membranes DOW FILMTEC Tape-Wrapped 4040 Elements for Commercial Applications Form No. 609-003640911, recuperado el 24 de Julio del 2020 encontrar en http://www.lenntech.com/Datasheets/Dow-Filmtec-TW30HP-4040.pdf

Encinas M. E. (2013) Preparación y caracterización de membranas compuestas resistentes al cloro a partir de 2,4,6 Trimetil MFenilendiamina (TMMPD) y cloruro de trimesoílo (TMC). Tesis Licenciatura no publicada, Instituto Tecnólgico de Sonora, Obregón, México.

Medina, J. A. (2000). Desalacion de aguas salobres y de mar. ósmosis inversa. Bercelona: Mundi-Prensa.

Morote Seguido, A. F., Manuel Rico Amorós, A. M. \& Moltó Mantero, E. (2017). La producción de agua desalinizada en las regiones de Murcia y Valencia. Balance de un recurso alternativo con luces y sombras. Documents d'Anàlisi Geogràfica, 63/2, 453-502.

Pavia D, Lampmam G, Kriz G \& Vyvyan J. (2009). Introduction to Spectroscopy (4 ${ }^{\mathrm{a}}$.ed.), Bellingham Washington: BROOKS/COLE.

Payeras, A. (2015). Ósmosis Inversa. Bonsai Menorca. Recuperado el 24 de Julio de 2020, de http://www.bonsaimenorca.com/articulos/articul os-tecnicos/osmosis-inversa/
Pontiéa, M., Sophie Rapenne, S., Thekkedatha, A., Duchesned, J., Jacquemetc, V., Leparcc, J. \& Sutyc, H. (2005). Tools for membrane autopsies and antifouling strategies inseawater feeds: a review. Desalination, 181, 75-90.

Robles Lizárraga, A., Martínez Macias, M. D. R., Encinas, M., Aganza, Ó., Rodríguez López, J., \& Dévora-Isiordia, G. E. (2019). Design of reverse osmosis desalination plant in Puerto Peñasco, Sonora, México. Desalination and Water Treatment, $\quad 175, \quad 1-10$. doi:10.5004/dwt.2020.24739

San Andrés, M., Chércoles, R., Gómez, M., \& de la Roja, J. M. (2010). Materiales sintéticos utilizados en la manipulación, exposición y almacenamiento de Obras de Arte y Bienes Culturales. Caracterización por espectroscopía FTIR-ATR. Proceedings X Jornada de Conservación de Arte Contemporáneo (GEIIC), Madrid, 33-51.

Tiravanti Beoutis, G. J. (2011). Síntesis, caracterización y propiedades mecánicas de resinas de poliéster insaturado a partir del reciclaje químico del poli (tereftalato de etileno). Tesis de Licenciatura, Pontificia Universidad Católica del Perú. Lima, Perú.

Yu, S., Liu, M., Lü, Z., Zhoub, Y. \& Gao, C. (2009). Aromatic-cycloaliphatic polyamide thinfilm composite membrane with improved chlorine resistance prepared from $\mathrm{m}$ phenylenediamine-4-methyl and cyclohexane1,3,5-tricarbonyl chloride. Journal of Membrane Science, 355, 155-164.

ÁLVAREZ-SÁNCHEZ, Jesús, SANTACRUZ-MUNGARRO, Alma Delia, DÉVORA-ISIORDIA, Germán Eduardo and MARTÍNEZ-MACIAS, Maria del Rosario. Membrane module autopsy used in the reverse osmosis process. Journal of Environmental Sciences and Natural Resources. 2020 